\title{
Productive performance of naked neck, frizzle and dwarf laying hens under various natural climates and two nutritional treatments
}

\author{
A. Garcês ${ }^{1 \#}$, N.H. Casey ${ }^{2}$ and P. Horst ${ }^{3}$ \\ ${ }^{1}$ Veterinary Faculty, Eduardo Mondlane University, C.P. 3670, Maputo, Mozambique \\ 2 Dept. Animal and Wildlife Sciences, University of Pretoria, Pretoria, 0002 South Africa \\ ${ }^{3}$ Institute of Animal Sciences, Humboldt University of Berlin, 10115 Berlin, Germany
}

\begin{abstract}
The productive performance of major genes for feather reduction (naked neck and frizzle) and body size reduction (dwarf) in a dual-purpose layer strain was evaluated in the subtropical coastal region of southeast Africa (Maputo, Mozambique). The experimental material consisted of eight different genetic groups, two diets (14.4 and 16.2\% crude protein) and two climatic seasons. Birds were caged individually in a laying house with natural light and ventilation. Traits measured were: temperature and relative humidity, body weight, age at first egg, egg number and weight, feed intake and mortality. The following were calculated: persistence, egg mass, feed efficiency, feed conversion, biological efficiency $\left(\mathrm{EMD} / \mathrm{BW}^{0.75}\right.$ ) and productivity $\left(\mathrm{EN} / \mathrm{BW}^{0.75}\right)$. The main results show that: (1) none of the feather-reducing genes significantly improved egg production or feed efficiency, although the naked neck $(\mathrm{Na})$ excelled in terms of biological efficiency and productivity; (2) the dwarf gene $(d w)$ was associated with delayed sexual maturity, production of fewer and lighter eggs, higher persistence, better feed conversion and higher survivability; (3) elevated temperatures restrained voluntary feed intake, egg number and weight, and body weight gain; (4) the lower dietary protein content resulted in decreased body weight. It was concluded that the genes were not equally responsive to the environments, which offers the opportunity for selective breeding.
\end{abstract}

Keywords: temperature, poultry, naked neck, frizzle, dwarf, egg production, laying hens.

\#Author to whom correspondence should be addressed; E-mail: rgarces@ mail.tropical.co.mz

\section{Introduction}

High environmental temperatures constrain the chickens' performance in intensive or extensive production systems. Dissipation of body heat is reduced, feed consumption is depressed and optimal reproductive and productive functions cannot be maintained. Heat tolerance is, among other factors, dependent on the degree to which the nocturnal environment provides release of the stored heat.

Breeding and selection strategies can be exploited to achieve the best possible production in unfavourable tropical environments. Particular major genes are known to improve heat endurance through different pathways, such as increase in heat loss by means of greater convection, conduction and radiation, decrease in metabolic heat increment due to lower basic metabolism and increase in the upper limit of critical body temperature. The naked neck $(\mathrm{Na})$ and the frizzle $(\mathrm{F})$ genes diminish the insulating power of the bird's plumage and thus are associated with increased heat loss. Reduced feathering density is directly associated with increased body surface temperature. The main effect of the sex-linked dwarf $(d w)$ gene is to reduce body weight. Although the relative advantage of dwarf hens in hot conditions is not consistent in literature, there is evidence that a small body is associated with a lower heat load and faster heat dissipation (Gowe \& Fairfull, 1995).

Interactions between genotypes and the environment for several traits are an established fact (Mathur \& Horst, 1989). Natural environments are characterised by seasonal variations in temperature, humidity and daylight length, making birds that perform well in the one environment to show impaired productivity in the other. Specific genotypes for specific tropical locations and production objectives should then be developed.

This study evaluated the contribution of major genes for feather reduction $(\mathrm{Na})$, feather curling and reduction $(F)$ and body reduction $(d w)$ to the efficiency of a dual-purpose layer strain under the climatic conditions of Maputo and two nutritional treatments. 


\section{Materials and Methods}

Day-old chicks were transported from the Institute of Animal Sciences of the Humboldt University of Berlin to Maputo, Mozambique $\left(25^{\circ} 58^{\prime} \mathrm{S}, 32^{\circ} 35^{\prime} \mathrm{E}\right)$ in January and August 1996 . The pullets were the offspring of a Dahlem Red experimental male line heterozygous for the naked neck $(\mathrm{Na})$, frizzle $(F)$ and dwarf $(d w)$ genes and a Rhode Island White female line hemizygous for the normal alleles of the three genes. The gene for light downs ( $\mathrm{Li}$ ) was incorporated to allow colour sexing of day-old chicks. Eight different combinations of genes for body size and feather coverage, constituting eight different genetic groups were segregated (Table 1).

The pullets were conventionally raised on floor and fed ad libitum egg type pullet commercial diets (Table 2). All chicks were exposed to the prevailing natural light. Genotypes were kept separately. Birds were vaccinated according to the recommendations of the local veterinary authority. At 18 weeks of age the pullets were moved to a tiered system of individual cages in a laying house with low side walls and wire netting to the roof for free flow natural ventilation.

Table 1 Genetic structure and size of experimental flock

\begin{tabular}{lcc}
\hline Phenotypic classification & Genetic specification & No. birds \\
\hline Normal feathered normal size & nana ff $D w-l i$ & 94 \\
Naked neck normal size & Nana ff Dw-li & 63 \\
Frizzle normal size & nana Ff Dw-li & 93 \\
Naked neck frizzle normal size & Nana Ff Dw-li & 65 \\
& & \\
Normal feathered dwarf & nana ff $d w-l i$ & 102 \\
Naked neck dwarf & Nana ff $d w-l i$ & 78 \\
Frizzle dwarf & nana Ff $d w-l i$ & 123 \\
Naked neck frizzle dwarf & Nana Ff $d w-l i$ & 79 \\
\hline
\end{tabular}

Birds were fed ad libitum the diets shown in Table 2. Seasonal environmental effects were studied in two experiments, characterised by opposite climatic and photoperiodic conditions, the first elapsing between January and November and the second between August and May. In each season, the eight genotypes were distributed equally to diets where diets were allocated to rows randomly. The individual females of each genotype were distributed randomly to individual cages within dietary treatment.

Table 2 Nutrient composition of diets

\begin{tabular}{lcccc}
\hline Calculated & Starter & Grower & \multicolumn{2}{c}{ Layer (1-52 wk) } \\
\cline { 4 - 5 } composition/kg & $0-6 \mathrm{wk}$ & $6-18 \mathrm{wk}$ & $\mathrm{HP}$ & $\mathrm{LP}$ \\
\hline $\mathrm{ME}(\mathrm{MJ})$ & 12.1 & 12.8 & 11.0 & 11.2 \\
Crude protein, $\mathrm{g}$ & 195.0 & 150.0 & 162.0 & 144.0 \\
Lysine, $\mathrm{g}$ & 9.0 & 6.4 & 8.0 & 8.1 \\
Methionine, $\mathrm{g}$ & 3.6 & 2.9 & 3.5 & 3.6 \\
Calcium, $\mathrm{g}$ & 8.0 & 10.0 & 36.0 & 36.2 \\
Phosphorus, $\mathrm{g}$ & 4.0 & 5.0 & 6.4 & 6.6 \\
\hline
\end{tabular}

Ambient temperature and relative humidity were recorded inside the laying house three times a day. Individual live weights of birds were measured on arrival in Maputo $(0 \mathrm{wk})$, fortnightly up to week 18 and every four weeks thereafter. The age at first egg was used to determine the sexual maturity. Egg production, including abnormal (soft-shelled, double-yolked and yolkless) eggs was recorded daily and all eggs laid on three consecutive days each week were weighed automatically to the nearest $0.01 \mathrm{~g}$. Feed consumption was measured every week by a weigh-back of residues in the individual feed troughs without correction for wastage.

Traits were calculated as follows: (1) Body weight of the pullets was standardised by means of the percentage proportion to the onset body weight (maturity index); (2) Performance traits were calculated by surviving hen; (3) Persistence was calculated for the first laying cycle as the ratio between the number of eggs produced in the third (31-52 wk) and the second (9-30 wk) laying periods; (4) Egg mass was calculated by multiplying the total number of eggs produced in a week by the average egg weight of that particular 
week, without correcting for abnormal eggs; (4) Feed intake was divided by the mean metabolic body weight in each period to give the ratio $\mathrm{FI} / \mathrm{BW}^{0.75}$; (5) Feed efficiency is the amount of feed consumed per unit of egg mass; (6) Feed conversion is the feed required per dozen eggs; (7) Biological efficiency is the ratio between daily egg mass and the mean metabolic body weight; (8) Productivity was calculated as the total number of eggs produced per mean metabolic body weight.

Dietary (where applicable), seasonal and genetic effects on the different observed and calculated traits were analysed using individual values of birds by means of the General Linear Model (GLM) procedure of the SAS programme (SAS Institute, 1994), according to the following model:

$$
\mathrm{Y}_{\mathrm{ijklmn}}=\mu+\mathrm{D}_{\mathrm{i}}+\mathrm{S}_{\mathrm{j}}+N a_{\mathrm{k}}+F_{1}+d w_{\mathrm{m}}+\mathrm{I}_{1 \rightarrow \mathrm{p}}+\mathrm{e}_{\mathrm{ijk} k m n}
$$

where $\mu=$ overall mean, $\mathrm{D}=$ laying diet; $\mathrm{S}=$ Season (or Experiment); $N a=$ naked neck locus; $F=$ frizzle locus; $d w=$ dwarf locus; $\mathrm{I}=$ interactions; $\mathrm{e}=$ error term.

\section{Results}

Figures 1 and 2 illustrate the ranges and fluctuations of photoperiod, temperature and relative humidity over the growth and laying cycles of experiments one and two.

Climatic season significantly ( $<$ 0.001) affected the growth of pullets (Table 3), with summer-winter birds (Exp. 1) being 4\% heavier at 18 wk than the winter-summer counterparts (Exp. 2). Feather reducing genes did not influence body weight. The growth patterns of non-dwarf and dwarf females are depicted in Figure 3 (i) showing that, within genotype, body weight differences between seasons were associated with variations in climate. Body weight expressed as a proportion of weight at sexual maturity (Figure 3, ii), shows that the birds grown in the light-increasing experiment were maturing faster than those raised when daylight was decreasing. As a consequence, sexual maturity was retarded by 17 days $(\mathrm{P}<0.001)$.

Table 3 Environmental and genetic main effects on performance traits (1-52 wk), LS-means

\begin{tabular}{|c|c|c|c|c|c|c|c|c|}
\hline \multirow[b]{2}{*}{ Factor } & & \multicolumn{7}{|c|}{ Traits ${ }^{1}$} \\
\hline & & BW 18-wk & $\mathrm{SM}$ & EN & EW & EM & BWG & LIV. \\
\hline & $\mu$ & 1,345 & 156 & 264 & 58.5 & 16.0 & 521 & 91.8 \\
\hline & SE & 7.2 & 0.5 & 1.3 & 0.1 & 0.1 & 8.3 & 1.1 \\
\hline \multirow[t]{3}{*}{ Diet } & HP & & & 265 & 58.7 & 16.1 & 549 & 92.2 \\
\hline & LP & -- & -- & 263 & 58.3 & 15.9 & 493 & 91.3 \\
\hline & $\mathrm{P}$ & & & & & & $* *$ & \\
\hline \multirow[t]{3}{*}{ Season } & Exp. 1 & 1,372 & 164 & 272 & 59.7 & 16.7 & 499 & 86.5 \\
\hline & Exp. 2 & 1,319 & 147 & 256 & 57.3 & 15.3 & 544 & 97.2 \\
\hline & $\mathrm{P}$ & $* * *$ & $* * *$ & $* * *$ & $* * *$ & $* * *$ & $* *$ & $* * *$ \\
\hline $\mathrm{Na}$ & nana & 1,345 & 155 & 262 & 58.4 & 15.9 & 540 & 92.3 \\
\hline locus & $\begin{array}{c}\text { Nana } \\
\mathrm{P}\end{array}$ & 1,345 & 156 & 266 & 58.6 & 16.1 & $\begin{array}{c}502 \\
*\end{array}$ & 91.3 \\
\hline \multirow{2}{*}{$\begin{array}{c}F \\
\text { locus }\end{array}$} & $f f$ & 1,361 & 156 & 265 & 58.3 & 16.0 & 531 & 91.5 \\
\hline & Pf & 1,329 & 156 & 263 & 58.7 & 15.9 & 511 & 92.1 \\
\hline \multirow{3}{*}{$\begin{array}{c}d w \\
\text { locus }\end{array}$} & $D w-$ & 1,615 & 154 & 294 & 61.2 & 18.5 & 645 & 89.4 \\
\hline & $d w-$ & 1,076 & 157 & 234 & 55.8 & 13.5 & 398 & 94.3 \\
\hline & $\mathrm{P}$ & $* * *$ & $* * *$ & $* * *$ & $* * *$ & $* * *$ & $* * *$ & $*$ \\
\hline
\end{tabular}

1 BW=Body weight; SM=Sexual maturity; EN=Egg number; EW=Egg weight; EM=Egg mass; BWG=Body weight gain; LIV=Liveability 


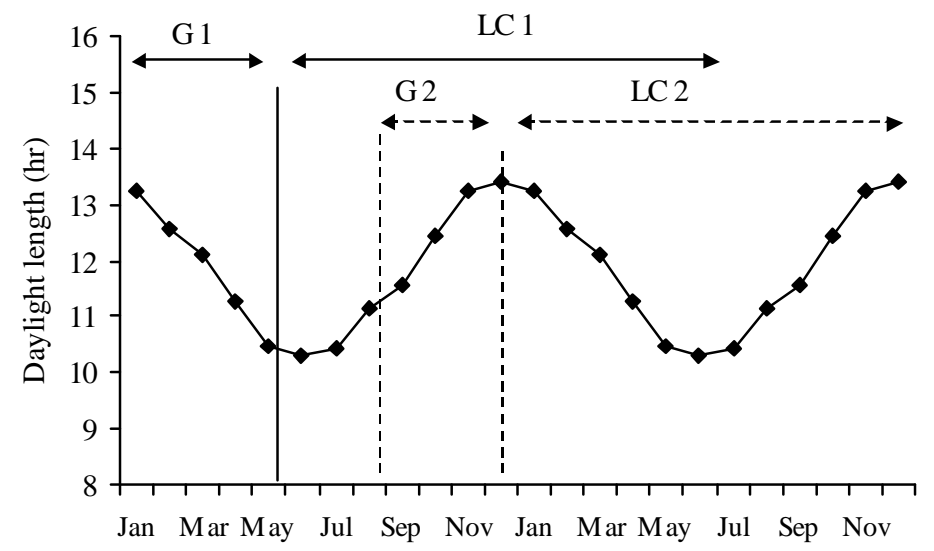

Figure 1 Average daylight length during growth (G1 and G2) and laying (LC 1 and LC 2) cycles in experiment one and two.
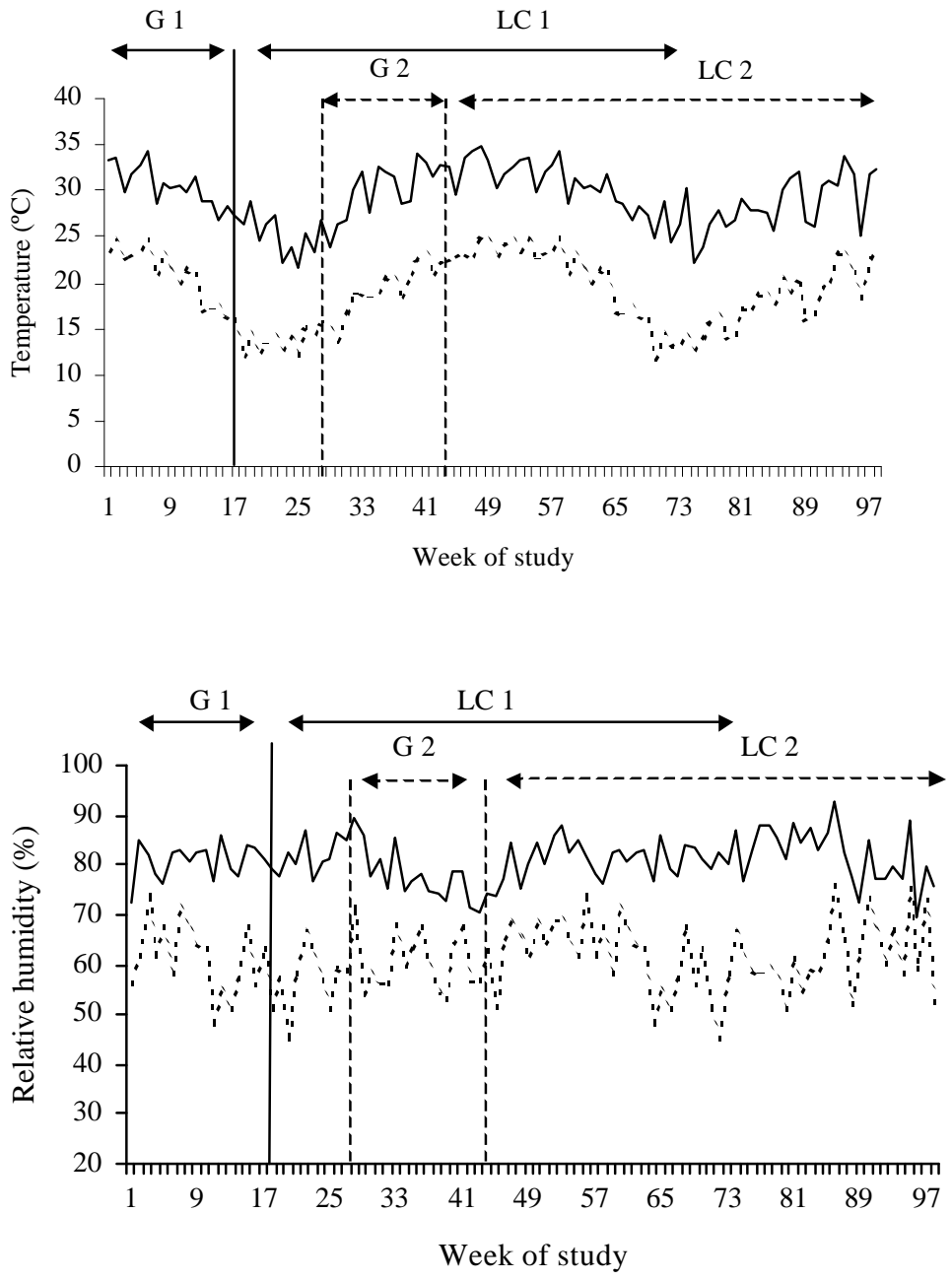

Figure 2 Room maximum (-) and minimum (---) temperature and relative humidity during growth (G1 and G2) and laying (LC1 and LC2) cycles in experiment one and two. 


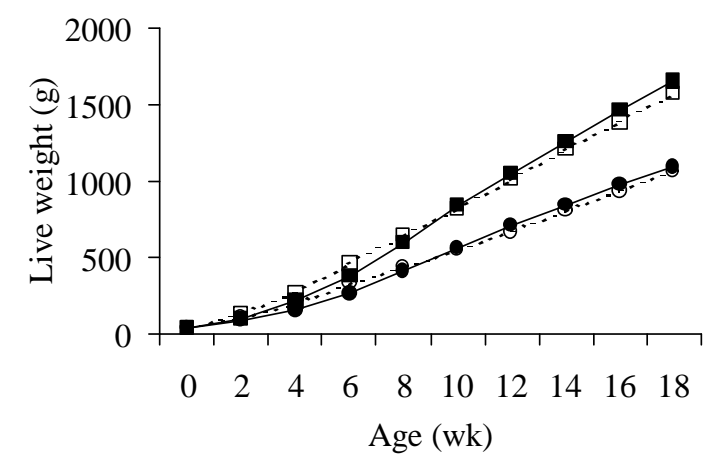

(i)

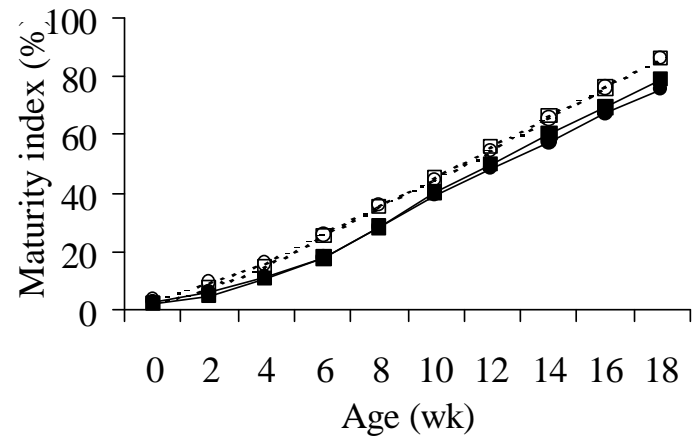

(ii)

Figure 3 Growth patterns of non-dwarf and dwarf pullets, (i) in absolute weight and (ii) when weight was expressed as \% of body weight at sexual maturity (maturity index)

(non-dwarf: $\square-\square$ Exp. 1, $\square---\square$ Exp. 2; dwarf: •—— Exp. 1, O----O Exp. 2).

Season did not influence productivity and feed conversion but did influence $(\mathrm{P}<0.01)$ all the other traits (Tables 3 and 4). Hens starting the laying cycle in the summer months (Exp. 2) produced fewer and lighter eggs and were less efficient in feed utilisation than those commencing in the cooler period of the year (Exp. 1). As a consequence, their biological efficiency was also lower. However, they gained more weight and showed higher persistence and lower mortality. Mortality in both experiments was mainly associated with the occurrence of severe heat stress (Exp. 1: $43{ }^{\circ} \mathrm{C}, 41 \% \mathrm{RH}$ in laying week 22; Exp. 2: $39.5^{\circ} \mathrm{C}, 40 \%$ RH in laying week 43).

Lower weight gain was the only trait associated with the lower dietary protein $(\mathrm{P}<0.01)$. Naked neck and frizzle females consumed considerably more feed per $\mathrm{kg}^{0.75}$ than the respective normal counterparts $(\mathrm{P}<$ $0.001)$, though the former hens excelled in terms of productivity and biological efficiency $(\mathrm{P}<0.05)$. The dwarfing gene reduced egg production and egg weight $(\mathrm{P}<0.001)$. Conversely, the gene was associated with superior efficiency, as dwarf hens consumed less feed and produced more eggs per metabolic weight, had lower mortality and needed a lower amount of feed per dozen eggs than the non-dwarf counterparts $(\mathrm{P}<$ $0.001)$.

Table 4 Environmental and genetic main effects on efficiency traits (1-52 wk), LS-means

\begin{tabular}{|c|c|c|c|c|c|c|c|}
\hline \multirow[b]{2}{*}{ Factor } & & \multicolumn{6}{|c|}{ Traits ${ }^{1}$} \\
\hline & & $\begin{array}{c}\mathrm{BE} \\
\mathrm{g} / \mathrm{d} / \mathrm{kg}^{0.75}\end{array}$ & $\begin{array}{c}\text { PROD } \\
\text { eggs/kg }\end{array}$ & PERS & $\begin{array}{c}\text { FI } \\
\mathrm{g} / \mathrm{d} / \mathrm{kg}^{0.75}\end{array}$ & $\begin{array}{c}\mathrm{FE} \\
\mathrm{kg} / \mathrm{kg}\end{array}$ & $\begin{array}{c}\mathrm{FC} \\
\mathrm{kg} / \mathrm{dz} \text { egg }\end{array}$ \\
\hline & $\mu$ & 28.2 & 171 & 0.93 & 67.0 & 2.36 & 1.70 \\
\hline & SE & 0.1 & 1.0 & 0.01 & 0.21 & 0.01 & 0.01 \\
\hline \multirow[t]{3}{*}{ Diet } & $\mathrm{HP}$ & 28.2 & 171 & 0.93 & 66.7 & 2.36 & 1.70 \\
\hline & LP & 28.2 & 172 & 0.93 & 67.2 & 2.36 & 1.70 \\
\hline & $\mathrm{P}$ & & & & & & \\
\hline \multirow[t]{3}{*}{ Season } & Exp. 1 & 28.9 & 173 & 0.89 & 67.8 & 2.32 & 1.70 \\
\hline & Exp. 2 & 27.5 & 169 & 0.97 & 66.1 & 2.40 & 1.70 \\
\hline & $\mathrm{P}$ & $* * *$ & & $* * *$ & $* * *$ & $* *$ & \\
\hline $\mathrm{Na}$ & nana & 27.9 & 169 & 0.92 & 65.6 & 2.34 & 1.69 \\
\hline \multirow[t]{2}{*}{ locus } & Nana & 28.5 & 173 & 0.93 & 68.3 & 2.38 & 1.71 \\
\hline & $\mathrm{P}$ & $*$ & $*$ & & $* * *$ & & \\
\hline $\mathrm{F}$ & $\mathrm{ff}$ & 28.1 & 171 & 0.92 & 66.0 & 2.32 & 1.67 \\
\hline \multirow[t]{2}{*}{ locus } & $\mathrm{Ff}$ & 28.3 & 171 & 0.93 & 67.9 & 2.40 & 1.72 \\
\hline & $\mathrm{P}$ & & & & $* * *$ & & $* *$ \\
\hline $\mathrm{dw}$ & Dw- & 28.2 & 164 & 0.93 & 67.7 & 2.38 & 1.79 \\
\hline \multirow[t]{2}{*}{ locus } & dw- & 28.2 & 179 & 0.92 & 66.2 & 2.34 & 1.61 \\
\hline & $\mathrm{P}$ & & $* * *$ & & $* * *$ & & $* * *$ \\
\hline
\end{tabular}

\footnotetext{
BE = Biological efficiency; PROD = Productivity; PERS = Persistence EN31-52 wk/EN9-30 wk; FI = Feed intake
} per metabolic weight; $\mathrm{FE}=$ Feed efficiency; $\mathrm{FC}=$ Feed conversion. 
The varied productive response of the three major genes to climate and diet is illustrated by the different interactions observed (Table 5). The dwarf pullets were $2 \%$ heavier at 18 wk of age and sexually immature for a further 20 days in the light-decreasing experiment (Exp.1). They consumed more feed (+6\%), produced higher mass $(+10 \%)$ and higher number of eggs $(+6 \%)$ per $\mathrm{kg}$ of metabolic weight, though showed lower persistence of laying in the winter-summer cycle (Exp. 1). The interaction on liveability indicates that, compared with the non-dwarf birds, almost three times less dwarfs died in the first experiment in association with heat stress.

Table 5 Environmental and genetic interactions on production traits (1-52 wk)

\begin{tabular}{|c|c|c|c|c|c|c|c|c|}
\hline \multirow[b]{2}{*}{ Trait } & \multicolumn{8}{|c|}{ Interaction } \\
\hline & Season x Gene & $\mathrm{P}$ & Season x Diet & $\mathrm{P}$ & Diet x Gene & $\mathrm{P}$ & Gene x Gene & $\mathrm{P}$ \\
\hline Body weight $18 \mathrm{wk}$ & $\mathrm{S} \times d w$ & * & & & & & & \\
\hline \multirow[t]{2}{*}{ Sexual maturity } & $\mathrm{S} \times N a$ & $* *$ & & & & & & \\
\hline & $\mathrm{S} \times d w$ & $* * *$ & & & & & & \\
\hline Egg weight & $\mathrm{S} \times F$ & $*$ & $S \times D$ & $*$ & $\mathrm{D} \times \mathrm{Na}$ & $*$ & & \\
\hline Egg mass & & & & & $\mathrm{D} \times N a$ & $* *$ & & \\
\hline Liveability & $\mathrm{S} \times d w$ & $*$ & & & & & & \\
\hline Biological efficiency & $\mathrm{S} \times d w$ & $* * *$ & & & $\mathrm{D} \times N a$ & $* *$ & & \\
\hline Productivity & $\mathrm{S} \times d w$ & $* *$ & & & & & & \\
\hline Persistence & $\mathrm{S} \times d w$ & $*$ & & & & & & \\
\hline Feed intake & $\mathrm{S} \times d w$ & $*$ & & & & & & \\
\hline Feed efficiency & $\mathrm{S} \times F$ & $*$ & & & $\mathrm{D} \times N a$ & $*$ & $N a \times F$ & $* *$ \\
\hline
\end{tabular}

Naked neck pullets matured 20 days later in the first experiment. Frizzle hens laid heavier eggs $(+5 \%)$ and were more efficient in feed utilisation $(-6 \%)$ in the experiment starting in the cooler months. Diet and season interacted on egg weight, as the birds fed on the LP diet laid lighter eggs (-2\%) in the second and hotter experiment. Naked neck birds under the LP regime laid heavier eggs and yielded higher egg mass $(+2 \%)$, and showed higher feed $(-2 \%)$ and biological $(+3 \%)$ efficiencies in comparison with their counterparts fed the HP diet. The only gene $\mathrm{x}$ gene interaction occurred between the naked neck and the frizzle genes on feed efficiency, indicating that $5 \%$ more feed per egg mass was needed by birds carrying both genes in comparison with the frizzle siblings.

\section{Discussion}

The depressing effect of high temperatures on growth of pullets experienced in this study concurs with previous studies (Njoya, 1995). The expected differences in body weight of dwarf and non-dwarf birds are in accordance with Guillaume (1976) and similarity in the rate of maturity, with Zelenka et al. (1986). The early sexual maturity (Exp.2) is attributed to light stimulation and the delayed sexual maturity of dwarf and naked neck birds indicates a greater sensitivity to decreasing photoperiods.

The cooler nocturnal temperatures eased the effect of diurnal heat strain, to the effect that featherreduced birds (naked neck and frizzle) had no significant productive advantage over the normal ones. Rauen et al. (1986) and Haaren-Kiso (1991) also reported no consistent superiority of those genes in less stressful environments. The greater egg weight of the frizzle layers in the second experiment was associated with a heavier body weight rather than an increased synthesis of egg components, under a warmer environment.

The depressing effect of the dwarf gene on egg number (-20\%), size (-9\%) and mass $(-27 \%)$ was as observed in previous studies (Horst et al., 1996). The characteristic increasing effect of the gene on productivity and feed conversion was also observed in this study. The lower biological efficiency observed in the second and more stressful experiment resulted mostly from reduced egg weight associated with lowered body weight. The higher survivability of small-bodied birds under acute heat stress was demonstrated only in the first experiment, as in the second acclimatisation might have harmonised the response of both body size groups.

Performance was largely dependent on the environmental conditions prevailing during the most productive part of the cycle. The favourable influence of a mild climate and increasing daylight length during the first months of production in the first experiment, together with the beneficial effects of late sexual maturity and higher body weight resulted in more and larger eggs produced with higher feed efficiency. This 
contrasted with the stressful climatic conditions and diminishing daylight length prevailing during equivalent period in the second experiment, as well as with lower body weight resulting from early maturity. In this experiment, the milder environment in the late stage of the cycle did not fully compensate for such detrimental influence on yearly production.

Voluntary feed intake was reduced by the higher temperatures in the second experiment, independently of body weight differences and hence different maintenance requirements of the hens. A comparison between experiments during a period with extreme temperature differences reveals that absolute feed intake was reduced $1.4 \%$ for each one-degree rise in temperature. This is similar to the results reported by Payne (1966) in equivalent temperature ranges.

Birds fed the low crude protein diet sustained egg production at similar levels to those fed the higher dietary protein, though at the expense of lower body weight gains in both experiments. However, they were unable to maintain comparable egg weight in the second experiment. In this cycle, not only was feed and hence aminoacid intake lower, but also body growth was higher, which certainly altered the partition of nutrients for production. The higher egg mass produced by naked neck birds fed on the diet with lower protein might be associated with higher retention of nitrogen related to synthesis of essential amino acids under low dietary protein, as reported by Touchburn et al. (1980).

\section{Conclusion}

These experiments showed that the selected genes responded differently to the environments (decreasing/increasing photoperiodicity, decreasing/increasing temperature and humidity ranges, and two levels of protein). This offers the opportunity for selective breeding, as the genes can be constituted into genotypes for the specific production system and climates.

\section{Acknowledgements}

The authors thank Dr. F. Otto and the GTZ (German Agency for Technical Cooperation) for the financial and material support of the study.

\section{References}

Gowe, R.S. \& Fairfull, R.W., 1995. Breeding for resistance to heat stress. In: Poultry Production in Hot Climates. Ed. N.J. Daghir, CAB International, UK, pp. 11-29.

Guillaume, J., 1976. The dwarfing gene dw: its effect on anatomy, physiology, nutrition, management. Its application in poultry industry. World's Poult. Sci. J. 32, 285-304.

Haaren-Kiso, A., 1991. Bedeutung des Gens für Lockenfiedrigkeit $(F)$ unter besonderer Berücksichtigung der Kombination mit anderen Majorgenen für das produktive Adaptationsvermögen von Legehennen an hohe Umgebungstemperaturen. Ph.D Thesis, Institute for Animal Production, Technical (Umboldt) University of Berlin.

Horst, P., Mathur, P.K. \& Valle Zarate, A., 1996. Breeding policies for specific tropical environments using appropriate combinations of major genes. Proc. $20^{\text {th }}$ World's Poultry Congress, New Delhi, pp. 633639.

Mathur, P.K. \& Horst, P. 1989. Temperature stress and tropical locations as factors for genotype $\mathrm{x}$ environment interactions in poultry production. Proc. Genotype $\mathrm{x}$ environment interactions in poultry production, Jouy-en-Josas (France), Ed. INRA, 83-96.

Njoya, J., 1995. Effect of diet and natural variations in climates on the performance of laying hens. Br. Poult. Sci. 36, 537-554.

Payne, C.G., 1966. Practical aspects of environmental temperature for laying hens. World's Poult. Sci. J. 22, 126-139.

Rauen, H.W., Horst, P. \& Valle-Zarate, A., 1986. Effect of the gene for feathering reduction and naked neck (Na) on the productive adaptability of laying hens under permanent high temperature. Arch. Geflügelk. $50,235-245$.

SAS, 1994. Statistical Analysis Systems User's Guide: Statistics. ( $6^{\text {th }}$ ed.) SAS Institute, Inc. Raleigh, North Caroline, USA.

Touchburn, S.P., Guillaume, J. Leclercq, B. \& Blum, J.C., 1980. Lipid and energy metabolism in chicks affected by dwarfism (dw) and naked neck (Na). Poultry Sci. 59, 2189-2197.

Zelenka, D.J., Dunnington, E.A. \& Siegel, P.B., 1986. Growth to sexual maturity of dwarf and nondwarf White Rock chickens divergently selected for juvenile body weight. Theor. Appl. Genet. 73, 61-65. 